\title{
JUST AND EQUITABLE CONSIDERATIONS FOR APPLICATIONS FOR THE EXTENTIONS OF NOTICES OF OBJECTION
}

\author{
GORDON D. DIXON*
}

The author analyzes the provisions in Canadian income tax law which provide discretion to the Tax Court to grant an extension of time, beyond the strict statutory period, for the filing of an objection to an assessment or a reassessment if the circumstances of the case are such that it would be just and equitable to do so, assuming that certain conditions precedent have been met. The author discusses two approaches available to the courts in determining whether the circumstances of a particular case are such as to make the granting of an extension "just and equitable": the constrained vision, which concentrates on the form of the process, or the unconstrained vision, which concentrates on the substance of the result. The author concludes that Canadian courts have followed a constrained vision in determining whether an extension of time is just and equitable in a given set of circumstances.
L'auteur analyze les dispositions de la Loi canadienne d'impôt sur le revenu qui confère d la Cour canadienne de l'impôt les pleins pouvoirs de prolonger, au-deld de la période stricte prévue par la loi, la période durant laquelle on peut déposer une objection d l'évaluation ou réveluation si les circonstances de l'espece sont telles qu'il est juste et équitable de procéder ainsi, a condition toutefois de remplir certaines conditions préalables. L'auteur présente deux approches permettant à la Cour de déterminer si les circonstances de l'espèce autorise a accorder une prolongation "juste et équitable": la premiere fait l'objet de restrictions et se concentre sur la forme de l'acte judiciaire; la seconde ne fait l'objet d'aucune restriction et s'attache a la substance du résultat. L'auteur conclut que la Cour canadienne a suivi la première approche pour déterminer si la prolongation est juste et équitable dans des circonstances données.

\section{TABLE OF CONTENTS}

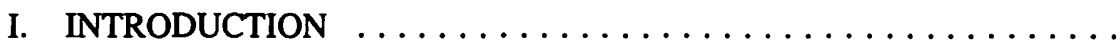

II. POWERS OF THE COURT AND NECESSARY

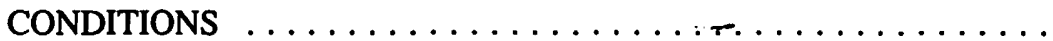

A. JUDICIAL REVIEW OF CONDITIONS

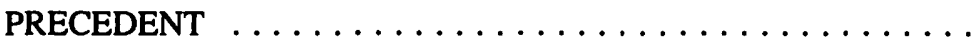

III. PHILOSOPHICAL FOUNDATION OF

JUSTICE AND EQUITY $\ldots \ldots \ldots \ldots \ldots \ldots \ldots \ldots \ldots \ldots$

A. CONSTRAINED VISION $\ldots \ldots \ldots \ldots \ldots \ldots \ldots \ldots \ldots, 770$

B. UNCONSTRAINED VISION $\ldots \ldots \ldots \ldots \ldots \ldots \ldots \ldots \ldots, 771$

C. SUMMARY ........................ 772

D. CONDITIONS PRECEDENT AND

JUSTICE AND EQUITY APPLIED $\ldots \ldots \ldots \ldots \ldots \ldots \ldots$

IV. CASE CIRCUMSTANCES AND JUSTICE

AND EQUITY APPLIED $\ldots \ldots \ldots \ldots \ldots \ldots \ldots \ldots \ldots$

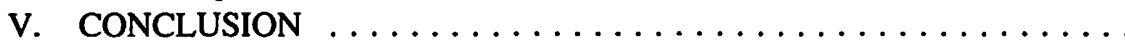

"Important as it was that people get justice, it was even more important that they should be made to feel and see that they were getting it. "1

- University of Lethbridge.

1. Lord Herschell, as cited in Gillis v. M.N.R., [1978] D.T.C. 6103 at 6106 (F.C.T.D.). 


\section{INTRODUCTION}

Canadian income tax law provides taxpayers with the positive ${ }^{2}$ right to dispute Revenue Canada's position with respect to the income tax consequences of past transactions when that position is in disagreement with the taxpayer's. Subsection 165(1) of the $\mathrm{Act}^{3}$ offers the procedural details which must be followed when asserting the right to object to an assessment or reassessment. ${ }^{4}$ One of the procedural details which must be adhered to is that taxpayers must object to Revenue Canada's position, if they desire to do so at all, within 90 days of the mailing of the notice of assessment. ${ }^{5}$ If a taxpayer is unable to comply with this time restriction, an extension of time within which to file a notice of objection may, in certain circumstances, be granted on application to the Tax Court of Canada.

The granting of an application for this extension of time is at the discretion of the Tax Court if "in its opinion the circumstances of the case are such that it would be just and equitable to do so." ${ }^{16}$ The purpose of this article is to first review the conditions which must be satisfied before an application for extension can be considered on the merits of its circumstances. Second, the article will review modern philosophical theory as it would apply to the just and equitable argument. Lastly, it will compare and contrast the modern argument with the decisions of the Courts and attempt to determine whether the Courts have followed a particular philosophical pattern.

\section{POWERS OF THE COURT AND NECESSARY CONDITIONS}

As stated previously, the Court may utilize its discretion in determining the appropriateness of the circumstances of a particular case. The wide discretionary power of the Court to grant extensions is apparently more pervasive than the preceding statute in that prior to the change in legislation, the Court could extend the time period only because of the death, incapacitating sickness or bankruptcy of a taxpayer. ${ }^{7}$

For a distinction between positive and moral rights, see, as an example, M.L. Berlin and W.F. Pentney, Human Rights and Freedoms in Canada (Toronto: Butterworths, 1987) at 4.

R.S.C. 1952 , c. 148, as am. S.C. 1970-71-72, c. 63 and as subsequently amended (herein referred to as "the Act"). Unless otherwise stated, statutory references in this article are to the Act.

The process of assessment is described in section 152 of the Act while the word is defined in subsection $248(1)$ as including a reassessment.

Subsection 165 (1) of the Act. Subsection 165(2) states further that the notice of objection, in duplicate, must be sent by registered mail to the Deputy Minister of National Revenue for Taxation in Ottawa.

6. Subsection 167(1) of the Act. The full relevant text of the subsection is: "Where no objection to an assessment under section 165 ... has been made or instituted within the time limited by that provision for doing so, an application may be made to the Tax Court of Canada for an order extending the time within which a notice of objection may be served .... and the Court may, if in its opinion the circumstances of the case are such that it would be just and equitable to do so, make an order extending the time of objection, appealing or making a request and may impose such terms as it deems just."

7. Subsection 61A(1), R.S.C., 1952 c. 148, as am. by S.C. 1970-71, (herein referred to as "the former Act"). 
The change in wording of the statute, and the resulting expansion of the power of the Court, occurred during the tax reform process of 1972. While it might be inferred that this statutory power is more pervasive than its predecessor, history would indicate that the magnification of the discretion of the court was not originally awarded as a specific objective of the 1972 tax reform. The former statute was apparently repealed on the suggestion of a Member of Parliament other than the then current Minister. ${ }^{8}$

The Court does not carry the unfettered power to award extensions of time. Particular conditions must be met before the Court can exercise its discretion where the facts indicate that it would be just and equitable to do so. These conditions are:

1. the application must be made within one year after the expiration of the time otherwise limited by the $A c t{ }^{9}$

2. the Tax Court has not previously extended the time for objecting to the particular assessment; ${ }^{10}$ and,

3. the Tax Court must be satisfied that the objection or appeal would have been undertaken within the 90 day limit, the application for the extension was brought as soon as circumstances permitted it to be brought, and there are reasonable grounds for objecting to or appealing the assessment."

It may be surmised that the Courts, in deciding the proper disposition of a particular case, must rest their deliberations not only on whether the technical conditions have been met, but also whether the circumstances of a particular case require a finding of "just and equitable". It may also be surmised that the aforementioned conditions constitute conditions precedent before a particular member of the Tax Court ascertains what constitutes social distributive justice.

\section{A. JUDICIAL REVIEW OF CONDITIONS PRECEDENT}

Since the enactment section 167 of the Act in 1972, some sixty applications have been presented to the Court. ${ }^{12}$ Of this number, four cases were denied on the basis that they did not fit within the condition that applications for extensions of time must be made within one year. ${ }^{13}$ Since time frames are stipulated in the statute, specific dates are seen to be of some importance when considering the effect of a particular provision.

There is in effect a two way transfer of documentation which commences the timing of notices of objection and applications for extensions of time. The initial transfer which

House of Commons Debates, 3rd session, 28th Parliament, 9663-9664, 10008-10010.

Paragraph 167(5)(a) of the Act.

Paragraph 167(5)(b) of the Act.

Paragraph 167(5)(c) of the Act.

For the purposes of this paper, the termination point of review was June 30,1989 . One case has not been included in this review as it was deemed by the Court to have been erroneously presented. See Stephens v. Q., [1977] C.T.C. 488 (F.C.T.D.).

See, for example, Grad v. M.N.R., [1979] C.T.C. 2078 (T.R.B.). For an interesting solution to the one year limitation, see Ronaldo Ouellet Ltée. v. MN.R., [1983] C.T.C. 2044 (T.R.B.). 
initiates the commencement of the time frames is the date on the notice of assessment or reassessment forwarded by Revenue Canada. The individual taxpayer then has $\mathbf{9 0}$ days from that date to forward a notice of objection. To the extent that the above limit can not be complied with, the taxpayer then has one year to file an application for an extension of time. The action of forwarding the application is the second transfer of documentation. If a particular circumstance can not be fitted squarely within the confines of this one year and 90 day limit, the Court does not carry the authority to hear the application for extension.

The case of Kramer v. M.N.R. ${ }^{14}$ speaks to the second transfer of documentation. Due to circumstances beyond his control, the taxpayers' accountant failed to forward notices of objection within the prescribed 90 day limit. Such notices were evidently signed by all parties within 15 days of such expiration and forwarded by registered mail the next day, together with an application for an extension of time. The accountant was notified approximately one year later that the applications had not been received by either Revenue Canada or the Tax Court. Canada Post did not have a record of the document being mailed and, since the accountant had misplaced the original registration receipt, could not trace its whereabouts. Upon learning of this loss, the taxpayers forwarded a second application.

In disposing of the case, the Court accepted both the credibility of the evidence that the appropriate documentation had been forwarded to the Court and that the taxpayers and their accountant had complied with the particular time frame of one year. The Court essentially concluded that in order for an application for an extension of time to have been made within the time limits, it did not have to have been received by the Court, but sent by the taxpayer. ${ }^{15}$ The Court further stated that "a stricter interpretation of the wording of section 167(5)(a) would, in the circumstances, remove the discretionary power which Parliament intended to confer on this Court in subsection 167(1)."16

Antoniou v. M.N.R. ${ }^{17}$ draws a different response from the Court with respect to the transfer of documentation which marks the commencement of time. The applicable rules allow a taxpayer to appeal a notice of assessment within $\mathbf{9 0}$ days. The rules further state that the date contained in the notice of assessment is the date of mailing the notice, ${ }^{18}$ and

14. Kramer v. M.N.R., [1984] D.T.C. 1709 (Tax C.C.).

13. In a different aspect, the Courts have determined the meaning of the word "sent" as a) to cause (a thing) to be conveyed or transmitted by an intermediary to another person or place, b) to dispatch ( a message, letter, telegram, etc.) by a messenger, post, etc. See Flanagan v. Q., [1982] D.T.C. 6341 at 6343 (F.C.T.D.). For application of the definition of the word sent within the parameters of section 167 of the Act, see Multi-Malls Inc. v. M.N.R., [1986] D.T.C. 1724.

16. Supra, note 14 at 1711 .

17. Antoniou v. M.N.R., [1988] 2 C.T.C. 2055 (Tax C.C.). See also Skirt Tog Industries Lid. v. M.N.R., [1982] C.T.C. 2156 (T.R.B.); Walker v. M.N.R. [1984] C.T.C. 2177 (Tax C.C.), and Ramos v. M.N.R.. [1983] C.T.C. 2744 (Tax C.C.). For a different result, see Lehrer v. M.N.R., [1982] C.T.C. 2152 (T.R.B.).

18. Subsection 244(14) of the Act. 
that the actual assessment has taken place at the date contained on the notice. ${ }^{19}$ It is therefore obvious that the initial time limit commences with the date of the mailing of the notice of assessment. The Act expands this operation by stating that, following the appropriate filing of an affidavit by Revenue Canada, there is prima facie evidence that the notice was mailed and, to the extent that a notice of objection cannot be found, that such notice was not received. ${ }^{20}$

In Antoniou, the taxpayer discovered, some two years after the fact, that he had been assessed differently than the manner in which he had filed his tax returns and now owed the Department the amount of tax which resulted from the assessment. The taxpayer then filed an application to extend the time for filing a notice of objection, which, in the circumstances, was now beyond the one year limit which commenced from the date contained on the original notice of assessment. The taxpayer's argument was that he had not received notification from the Department that the particular taxation years were under assessment.

The court accepted the evidence, and credibility thereof, offered by the taxpayer in that it concluded that he had not received the notice of assessment. In its deliberations, the Court stated that: ${ }^{21}$

It would seem difficult to have a statutory period commence without rights being given to a taxpayer. When given a right he must be in a position to act. By being unaware of any problem the applicant could not commence any remedial action.

The Court therefore concluded that in order for the 90 day time limit to commence with the date of mailing the notice of assessment, such notice, more importantly, must be received by the taxpayer. In citing a previous decision which concluded that no assessment existed to which an objection could be taken, ${ }^{22}$ the Court found: ${ }^{23}$

In the present case .... no valid receipt of the mailing of the notice having been established, after evidence indicated it had not been received, the time limited by subsections 165(1) and 167(1) of the Act for objecting to the reassessment has not expired. There is no basis to apply for an extension of time as the manner in which the purported reassessments was carried out was insufficient to complete the reassessment process.

It would appear that this bi-directional transfer of documentation carries divergent impacts. Notwithstanding that the recipient of the documentation in these two fact situations was different, the conclusions reached by the Court travel in opposing directions. It may be that the inherent nature of receipt will depend on who does the sending, the Minister or the taxpayer.

No decisions were rendered which centred on whether the Tax Court had previously granted an extension of time.

19. Subsection 244(15) of the Act.

20. Subsection $244(10)$ of the Act. The current subsection, as revised by R.S.C. 1985, c. 55, subsec. 184(1.1), has deleted the reference to prima facie.

21. Antoniou v. M.N.R., supra, note 17 at 2059.

22. Bhatti v. M.N.R. [1981] C.T.C. 2555 (T.R.B.).

23. Antoniou v. M.N.R., supra, note 17 at 2059. 
The majority of the cases before the Court have been decided on the basis of whether the particular situation under consideration fits the conditions of whether the Tax Court has been satisfied that the objection or appeal would have been undertaken within the 90 day limit, the application for the extension was brought as soon as circumstances permitted it to be brought, and there were reasonable grounds for objecting to or appealing the assessment. ${ }^{24}$

In deciding the issues which surround the last condition, the Courts have been reluctant to consider the merits of a proposed appeal. The test which has apparently prevailed is that the taxpayer's position, as opposed to that of Revenue Canada, must initially surmount a common standard of reasonableness. To prejudge the outcome of a proposed appeal would obviously bias the ensuing review. This reasonableness standard would be difficult to articulate and the Courts have not attempted to offer a position on the matter other than to state that matters of interpretation should be free of ambiguity. ${ }^{25}$

The penultimate condition articulated above has caused concern for the Court and has been the subject of interpretations based on the factual circumstances of each case. The phrase "as soon as circumstances permitted" denotes "with all due dispatch". The unique set of circumstances which would cause some delay, however, are not tempered by the common notion of just and equitable. Since the Courts have not been constrained by social distributive justice in deciding what appropriate circumstances justify tardiness, the particulars surrounding a given case have been given a rather expansive airing.

In Thistle ${ }^{26}$ the taxpayer's representatives applied for an extension of time some eight months after the expiration of the 90 day limit for filing notices of objection. The taxpayer's representatives argued that, pursuant to the requirements of subsection 165(1) of the Act, the length of time was necessary to gather all the relevant information necessary to prepare the notice of objection. Subsection 165(1) of the Act requires that the notice of objection must be filed "setting out all reasons for the objection and all relevant facts." The contention was that the requirement necessitated a full exposure and investigation of the facts and further, the time taken was a necessary prerequisite in satisfying the condition. The Court accepted this argument to the extent that by satisfying the legislated requirement, the taxpayer's application was brought as soon as circumstances permitted, that is, the circumstances necessitated the lengthy delay.

Paragraph 167(5)(c) of the Act.

This reasonableness standard has been subject to review in the case of Reid v. M.N.R., [1985] 2 C.T.C. 2396 (Tax C.C.). After subjecting both sides of the dispute to an analysis, the Court found that where there was any possible ambiguity of a particular section, the taxpayer must be absolutely certain that a particular interpretation applies and, therefore, granted the taxpayer's application.

Thistle v. M.N.R., [1983] C.T.C. 2656 (Tax C.C.). In an earlier case, Wright v. M.N.R., [1983] C.T.C. 2493 (T.R.B.), the taxpayers discovered, some two years later, that their original notice of objection had been misplaced. One and a half months later, the taxpayer's representative applied for an extension of time. This delay was apparently attributable to the lack of receipt of a retainer by the taxpayer's representative. Evidence was not offered to explain the lack of payment by the taxpayers nor the requirement of the representative for receipt. The Court concluded that the application was not made as circumstances permitted and dismissed the case accordingly. 
While the above case may indicate that the Court is predisposed to accept the professionalism of a taxpayer's representative, the opposite outcome may also be expected when a professional advisor conducts their obligations in a negligent or haphazard manner. In Harris, ${ }^{27}$ the taxpayer's accountant did not file an application until six months after the initial 90 day period, believing he had one year in which to accomplish the task. While this particular case was important at the time for other reasons, ${ }^{28}$ the comments of the Court are pertinent with respect to the inherent duty of taxpayers and the discharge of their responsibilities under the Act. In denying the application, the Court essentially rejected the notion that negligence or errors by a professional representative constitute a reasonable rationale for delaying an application. In rejecting this line of argument, the Court stated that: ${ }^{29}$

\footnotetext{
Where an applicant knows that a document must be signed or some action taken within a prescribed period of time he retains the responsibility to ensure that those steps are taken. It is not sufficient for a taxpayer to simply turn the matter over to an accountant and to forget it.
}

The essential principle now espoused is that taxpayers can not abrogate their responsibility by referring matters to a professional advisor. ${ }^{30}$ It would also seem evident that where professional advisors are not providing adequate service to their clients, these advisors may suffer the consequences of less than successful applications under section 167 of the $A c t .^{31}$

Harris v. M.N.R., [1985] D.T.C. 302 (Tax C.C.).

28. Prior to the decision in Harris, there was considerable activity in the Courts with respect to the taxpayer being deprived of his rights as a result of an error of counsel. Bourdon v. M.N.R., [1984] C.T.C. 2654 (T.R.B.) established the principle with respect to applications for extension under section 167 of the Act that "a party must not be deprived of his rights on account of an error of counsel where it is possible to rectify the consequences of such error without injustice to the opposing party." This view was drawn from two cases, Cite de pont Viau v. Gauthier Manufacturing Limited, [1978] 2 S.C.R. 516 and Murray Bowen v. City of Montreal, [1979] 1 S.C.R. 511, which did not purport to address any tax issues. Reference could be had to Menzies v. M.N.R., [1984] C.T.C. 2564 (Tax C.C.) and Thody v. MNR, [1983] C.T.C. 2741 (T.R.B.) which deal specifically with applications for extensions and particular responsibilities under the Act. It is interesting to note that the decisions with respect to this issue did not address any perceived difference in the meaning of the word "counsel" as it related to either accounting or legal professionals. Commentators would generally offer the opinion that Harris is an important case because the Tax Court distinguished the above principle as it applied to applications for extension under section 167 of the Act. Harris v. M.N.R., supra, note 27 at 304.

30. In an earlier decision which preceded Bourdon, supra, note 27, the Court indicated, with respect to a professional advisor's somewhat haphazard handling of an assessment, that "... it would be doing a wrong service to professionals to give them the idea that so long as they advise the Board that there was some mistake in their operation that the application would automatically be granted." See Arnone v. M.N.R., [1978] D.T.C. 22 at 23 (T.R.B.). There is, however, precedent to suggest that an extension should be granted where the delay is not attributable to "culpable negligence" of the taxpayer. See Thody v. M.N.R. supra, note 28.

31. Such consequences were at least alluded to by the Tax Court in the case Minuteman Press of Canada Company Limited v. M.N.R., [1987] C.T.C. 2231 (Tax C.C.). In commenting on the applicability of unprofessional attention to the matter by a professional advisor as a circumstance worthy of consideration in an application for extension under section 167 of the Act, the Court stated, at 2236:

Although incompetence and negligence are factors which I can consider in determining whether the order sought by Minuteman ought to be granted, they remain matters which must perforce be determined at a different time in a different forum. 
Not only must taxpayers assume the responsibility of their own actions when they have engaged a professional advisor who acts negligently, it would now appear that these same individuals must also assume responsibility when a professional advisor is engaged by the taxpayer to act in their stead in any manner after the expiration of the initial 90 day period. In $R$. v. Arthur $C$. Pennington, ${ }^{32}$ the taxpayer filed his original Notice of Objection three days after the initial 90 day limit had expired. He was subsequently advised by Revenue Canada that the notice was late but that he was entitled to apply for an extension provided the application was made as soon as possible and not later than one year following the 90 day limit. The taxpayer referred the matter to his professional advisor for negotiation and settlement. He subsequently concluded that a settlement of the issue would not be forthcoming, and therefore, filed an application for an extension before the termination of the one year time period.

While the Tax Court ${ }^{33}$ accepted the taxpayer's arguments that the phrase "as soon as circumstances permit" should be interpreted as liberally as possible, the Federal Court of Appeal disagreed. In a majority decision, the Court concluded that the aforementioned phrase should be given a restrictive interpretation. In essence, the taxpayer must now "make his application as early as, under the particular circumstances, he could reasonably be expected to get an application ready and present it. ${ }^{134}$ It would now appear that there are few circumstances that palliate the taxpayer's responsibility to promptly file an application for an extension within the purview of the conditions precedent of subsection 167(5) of the Act. $^{35}$

The last condition which must be satisfied is that, but for the just and equitable circumstances which gave rise to the application for extension, the initial objection would have been filed within the 90 day period. ${ }^{36}$ It is interesting to note that this particular condition is unique in that it is the only one which directly considers the relevance of the circumstances which caused the application to be made. It could be inferred that if the circumstances which caused the inability to file an objection within the original period are just and equitable, then it follows that the application should be granted. The obvious question which must be satisfied is the determination of what is just and equitable.

\section{PHILOSOPHICAL FOUNDATION OF JUSTICE AND EQUITY}

In determining the context within which the just and equitable problem can be discussed, it is necessary to illustrate that the phrase is an apparent aberration of the administration of the rules. Put succinctly, if a taxpayer cannot fit their particular situation within the confines of the rules which apply to everyone, then the individual may

32. R. v. Pennington, [1987] 1 C.T.C. 235 (F.C.A.D.).

33. Pennington v. M.N.R., [1986] 1 C.T.C. 2497 (Tax C.C.).

34. Supra, note 32 at 237.

35. For an interesting analysis of Pennington, see V. Krishna, "Obtaining Extension of Time to File Notice of Objection: The Palm Tree Begins to Wither" (1987) Canadian Current Tax Vol. 2 No. 4 A1-A3. One can only speculate whether the decision in Thistle, supra, note 26 is consistent with the Court's restrictive interpretation of the phrase "as soon as circumstances permit". 
request the application of rules which apply only to that individual. The initial premise of discussion is the just and equitable treatment of individuals who have placed themselves beyond the parameters of the procedural rules of the Act which have universal application.

To the extent that individuals have requested the application of rules which are at the disposal of the Court, the primary consideration of the individual and the Court, is whether the just and equitable criteria is to be applied on a process or outcomes basis.

Social distributive justice has been concerned, historically, with results or outcomes from a process. From the utilitarian to the contractarian perspective, justice has been categorized as the comparison of the individual to society. If, through the application of process, an individual receives a result that is just, then society is conducting itself in a just manner. The determination of whether the outcome is just is dependent on the philosophical perspective utilized to judge the result. Little has been offered to explain whether process employed is the objective when determining what is just and equitable; the emphasis has generally been that if the result after the application of process is just, then justice and equity are being served. This categorization of process versus outcomes has been explained as the conflict between constrained and unconstrained visions. ${ }^{37}$

\section{A. CONSTRAINED VISION}

In the constrained vision, justice is "the application of impersonal rules of law"38 or the process by which individuals may seek redress given knowledge that the rule exists. The basic tenet of this view is that if social justice is deemed to be a desirable result, then it follows that, given a rule exists, that rule will eventually be defeated. ${ }^{39}$ This defeat is inevitable because the constrained vision views the process, rather than the result, as the objective. It appears self evident that if the result becomes the objective, then the process or the rule of law must be altered and therefore defeated.

This potential defeat of the rule of law is probably the rationale for the existence of the permissive provisions contained in section 167 of the Act. If relief from the timing provisions which commence the objection process did not exist, and the relief did not purport to deal with unique circumstances of a particular situation, the collapse of the objection procedure would result.

The constrained vision is also premised on the notion that "once the law has drawn the boundaries of discretion, courts should avoid second-guessing the actual exercise of that

T. Sowell, A Conflict of Visions: Ideological Origins of Political Struggles, (New York: William Morrow, 1987).

38. Ibid. at 198.

39. F.A. Hayek, an alleged proponent of the constrained vision, offers the sentiment that "distributive justice is irreconcilable with the rule of law." F.A. Hayek, Law, Legislation and Liberty, Vol. II, (Chicago: University of Chicago Press, 1976) at 86. 
discretion. ${ }^{400}$ For this vision, the aforementioned conditions precedent are the boundaries of discretion established for the Court, and their breach is not conceivable. It can also be discerned that the dictates of the Court, particularly the majority decision in Pennington, ${ }^{41}$ fall squarely in the perspective that parameters, once established, should not be eroded. It therefore follows that narrow interpretational guidelines would be followed when applying the conditions as stated above. Additionally, for the constrained vision, the decision in $\mathrm{Harris}^{42}$ to not allow negligent or haphazard conduct of a professional advisor influence the outcome of an application for extension is further support of this narrow interpretational philosophy. The view could also be offered that the distinction between sending and receiving documents which commences the objection process is without foundation; ${ }^{43}$ the constrained vision would apply the rule of law equally.

\section{B. UNCONSTRAINED VISION}

The opposite of the constrained vision holds the view that results are paramount in the pursuit of social justice. Notwithstanding that some proponents of the unconstrained vision had difficulty with the application of rules, ${ }^{44}$ the more popular advocates of this view would argue that justice can be served if the result obtains the algebraic sum of satisfaction ${ }^{45}$ or the fact that, under a "veil of ignorance", the individual's contract with society will produce a just and equitable outcome consistent with that contract. ${ }^{46}$ In effect, this vision demands for the less fortunate not merely charity, but justice. It demands of its laws not merely procedural rules but just results - with the former yielding to the latter in case of conflict. ${ }^{47}$

In addition, this vision would argue that rules contained in the law are suggestive of prevailing moral standards and rigid procedural guidelines. In any attempt to reach a just solution, the application of the moral standard, as embodied by law, will yield a just result if, and only if, the interpreter gives recognition to the concept of equality of results to specific circumstances.

To the extent that the equality of results is the just outcome, it therefore follows that in the application of section 167, the Courts must possess the capacity whereby an

40.

41.

42.

43.

Sowell, supra, note 37 at 163.

$R$. v. Pennington, supra, note 32.

Supra, note 27.

See Kramer v. M.N.R., supra, note 14 and Antoniou v. M.N.R., supra note 17.

"It is objected that two actions that produce identical overall amounts of good and evil will differ in value if one involves the breach of a rule, .... but the other does not." A. Quinton, Utilitarian Ethics, (New York: St. Martin's Press, 1972) at 72.

s. J.S. Mill, Utilitarianism (New York: Bobbs-Merrill, 1957). See also J. Harrison, Humes's Theory of Justice (Oxford: Clarendon Press, 1981) particularly Section III, at 264-280 and J.J.C. Smart and B. Williams, Utilitarianism: For and Against, (Cambridge: University Press, 1973). 
assessment of comparative positions of taxpayers can be made. It may be inferred that this comparison must be made between the amount of justice a taxpayer would have received if an objection had been filed within the original 90 day period and the amount of expected justice if the application for extension is granted. If this were not the comparative position, there would have been little need to include the provision that the taxpayer would have filed an objection within the 90 day period but could not because of the unique circumstances under consideration.

Those endorsing the unconstrained vision would subscribe to the minority opinion in Pennington $^{48}$ to the extent that unusual circumstances prompted the lengthy delay in applying for an extension and the application of a reasonableness test is the best indicator of equality of results. This reasonableness test could be described by those holding the unconstrained vision as drawing boundaries defining acceptable procedures but then judging the substance of what those procedures produce within the boundaries. ${ }^{49}$

\section{SUMMARY}

If the process as described in section 167 were to be applied on a basis which is consistent from case to case, the constrained vision would conclude that the rule of law, and particularly the conditions precedent described in subsection 167(5) of the Act, would provide for a just and equitable conclusion in each case. The unconstrained perspective would yield the opinion that the equality of results, after the application of the process, must withstand the test of reasonableness. The substance of the result must take precedence over the form of the process. ${ }^{50}$ It would be a trite observation to state that the choice of process or result as the working definition of the phrase "just and equitable" would influence the outcome of a particular fact situation. The analysis of fact situations and their individual outcomes should assist in the comprehension of "just and equitable" as applied by the Courts and, perhaps, facilitate further application. ${ }^{51}$

48.

Sowell, supra, note 37 at 164 . Geoffrey Marshall, in speaking about standing by precedents, states: "This may be a tendentious expression of an activist philosophy of common law adjudication since it implicitly and over-simply contrasts justice with following precedent. It also does not clearly separate the mild thesis that where there is uncertainty or conflicting or unclear precedents the courts should seek to do what is just, from the stronger thesis that where they are thought to work injustice even clear precedents and established rules should be changed and made to yield to bold judicial views about what promotes justice or freedom." G. Marshall, "Theorizing About the Judicial Role" in Anne Bayefsky, ed., Legal Theory Meets Legal Practice, (Edmonton: Academic Press, 1988) 73 at 75 .

50. The debate of substance over form conforms itself to the conflict of constrained versus unconstrained visions. The closed determination versus open process of these two visions is amenable to the contrasting suppositions of substance over form. Geoffrey J. Lanning has provided the template for this comparison in "The Real-Politik of Taxation: Substance and Form, Tax "Lawmaking", and the Basic Tax Ideologie: (1988) 34 Wayne Law Review 1485, and in particular the chart comparing substance and form found at 1564-1572.

st. Philip Pettil offers the view that processes such as the judicial system are perfectible. He states "the purpose of social institutions, where institutions may mean groups or practices, is to serve the interests of individuals and ... that such institutions are intrinsically perfectible ..." P. Pettit, Judging Justice (London: Routledge, 1980) at 45. 


\section{CONDITIONS PRECEDENT AND JUSTICE AND EQUITY APPLIED}

The application of the working definition of "just and equitable" would be employed initially where a particular fact situation attempted to surmount the conditions precedent contained in subsection 167(5) of the Act. As stated above, taxpayers must offer sufficient evidence to indicate that they would have exercised their right of objection within the original 90 day period but could not because of the fact circumstances unique to their situation. In applying this condition, the Courts have indicated that taxpayers, at a minimum, must possess the willingness to object before meeting this initial requirement.

Willingness to object has been identified by the Courts on a number of occasions. In Richmond Country Club v. M.N.R., ${ }^{52}$ the taxpayer had received a notice of assessment from Revenue Canada which differed from the position originally filed with the tax return. Subsequent to the 90 day period, the taxpayer received new information with respect to the assessment and obtained advice that the assessment should now be contested. An application for extension was then made. In deciding to dismiss the application, the Court observed that one of the conditions which must be satisfied is that the taxpayer would have filed a notice of objection within the original time frame but did not or could not because of the existence of unique circumstances. The Court rejected the above circumstances as falling within the parameters of the working definition of just and equitable. In essence, the Court decided that the taxpayer could have objected if they had wanted to; the circumstances of the case indicated that based on the knowledge obtained during the initial 90 days, the taxpayer did not want to object to the assessment. The Court commented: $:^{53}$

If (the taxpayer) had had an objection, it would have filed a Notice of Objection. To accept that as fulfilling the condition precedent in section $167(5)(c)$ (i) of the Act, in my view, would negate the major purpose of that section, as I interpret it, which is to reinforce and require immediate, serious and virtually final consideration of the assessment when it is received.

This view was repeated in Fraser Estate v. M.N.R., ${ }^{54}$ where the taxpayer was unsuccessful in persuading the Court that new information discovered subsequent to the original 90 day period was sufficient to indicate a willingness to initiate the objection process. ${ }^{35}$

From a form or process perspective, the rejection of the above applications for the reason that the taxpayers lacked the knowledge ${ }^{56}$ to substantiate their claim of possessing

Richmond Country Club v. M.N.R., [1984] D.T.C. 1088 (Tax C.C.).

Ibid. at 1089.

E.C.F. Fraser v. M.N.R., [1989] 1 C.T.C. 2055 (Tax C.C.).

In D. Papalia Drywall Construction Ltd. v. M.N.R., [1982] C.T.C. 2194 (T.R.B.) the Court rejected arguments by the taxpayer that its attention to a court case, an accident to a relative and the absence of an internal accountant explained why the objection was not filed within the original time period. The Court alluded to the reasonableness standard in its reasons for decision.

In Green v. M.N.R., [1987] 1 C.T.C. 2341 (Tax C.C.), the taxpayer apparently possessed full knowledge of the circumstances during the initial time period. In rejecting the application, the Courn stated, at 2342, "In the present case upon receipt of the assessment notices in the years in question the applicant had the knowledge or means of knowledge of the problem. The fact that he did not perhaps realize this until a later date is no excuse." It would appear possession of knowledge and 
the willingness to object is consistent with the constrained vision. An individual's own knowledge is inadequate when compared to the knowledge of societies. It is societal knowledge, as evidenced by society's rules, which govern the dispersal of justice. ${ }^{57}$ To the extent that an individual cannot meet the minimum expectation of knowledge, and in this instance within a given time frame, then justice is served if the rule remains intact.

The unconstrained vision or results perspective would offer the view that "the best conduct of social activities depends upon the special knowledge of the few being used to guide the actions of the many." ${ }^{\text {" }} 8$ This special knowledge would utilize individual comparisons as the standard of judgment and, in the present case, comparisons would be made to individuals who possessed sufficient knowledge to initiate the objection process within the given time table. Whether or not the comparison of these positions would result in a different decision is open to speculation; however, if the common ground of minimum expectations and requirements is applied to the case's circumstances. With access to professional advisors, coupled with a taxpayer's specific knowledge of the facts, it would not be unreasonable to require commencement of the objection process within the applicable time frame. These minimums may indicate, therefore, that the decision to reject the requests for extension fell within the boundaries of just results.

\section{CASE CIRCUMSTANCES AND JUSTICE AND EQUITY APPLIED}

The first application decided under the current legislation, Savory Beach v. M.N.R., ${ }^{59}$ apparently set the perspective for the Court, and the underlying constrained versus unconstrained approach, to the application of section 167 of the Act and the appropriate circumstances which would apply. Although not referencing the unique circumstances of this particular case, the Court accepted the application, but in so doing, established the parameters within which future decisions would be made. With the apparent approval of the constrained vision, the Court stated: ${ }^{60}$

This Board takes the position that the granting of an extension in time under section 167 will be the exception rather than the rule. Human frailty will no doubt give rise on occasion to unusual circumstances,... wherein it is fair and reasonable to grant such an extension. However, to simply grant such extensions and imply that all applications will be granted, is to make a mockery of the period of limitations set down in the Act. Therefore this Board will, in all cases, ... require exceptional circumstances before any such application will receive approval.

The requirement of exceptional circumstances parallels the constrained vision's notion of applying the law in an environment of processes rather than the unconstrained atmosphere of contemplation of all the circumstances.

the awareness of that possession may be identical circumstances.

"There is thus more 'intelligence' incorporated in the system of rules of conduct than in man"s thoughts about his surroundings." F.A. Hayek, Law, Legislation and Liberty, (Chicago: University of Chicago Press, 1979), Vol. III, at 157, as quoted by Sowell, supra, note 37 at 41 .

s8. Sowell, supra, note 37 at 46.

59. Savory Beach Lands Lid. and Savory Resort Properties Lid. v. M.N.R., [1972] D.T.C. 1497 (T.R.B.).

60. Ibid. at 1498 . 
In subsequent individualized cases, exceptional circumstances would appear to be the norm in successful applications. Unique facts which succeeded have included sickness, ${ }^{61}$ hospitalization, ${ }^{62}$ bankruptcy, ${ }^{63}$ and missing the initial 90 day period by an insignificant interval. ${ }^{64}$ Only the latter circumstances have breached the restrictive boundaries of the former provision. ${ }^{65}$

Fact situations which have not been successful, and therefore have been categorized as unexceptional, have included such factors or combination of factors as marital difficulties, ${ }^{66}$ reliance on professional advisors, ${ }^{67}$ and illness of internal accounting personnel. ${ }^{68}$ In rejecting these situations, the Courts have generally observed that the taxpayers had failed to discharge their responsibilities under the Act to ensure that a notice of objection was forwarded within the appropriate time frame or that there simply was not sufficient attention devoted to the matter.

In one particular case of note, the Federal Court of Appeal rejected a taxpayer's appeal of a dismissal of an application extension, ${ }^{69}$ and in so doing, the Court concluded that the particular taxpayer had gone beyond the bounds of irresponsibility. In confirming the Tax Court's dismissal, the Court stated: ${ }^{70}$

\footnotetext{
Ignorance of the law and reckless disregard for the exercise of one's rights are two very different things, and the latter is a very relevant consideration indeed to the exercise of a discretion on just and equitable grounds.
}

From a constrained vision perspective, individuals may make their own decisions with respect to rights within the boundaries of legal processes. To the extent that these rights are exercised, then the legal process would not scrutinize the result of this exercise to the extent that the individual was or was not achieving justice. It can also be said that if an individual chooses not to exercise a right, that individual should not look to the legal

Lesage v. M.N.R., [1982] C.T.C. 3070 (T.R.B.).

62. Logan v. M.N.R., [1981] C.T.C. 3072 (T.R.B.). The facts of this case indicate that the taxpayer was hospitalized for two weeks, in a full body cast for two months and in a partial body cast for a further two months.

Reaume v. M.N.R., [1989] 1 C.T.C. 267 (F.C.A.D.). Bankruptcy has not always been seen as an acceptable circumstance to grant an extension. Notwithstanding the apparent flexibility of the current statute, as compared to the former, the Court has rejected this fact. See Shore Trustee v. M.N.R. [1978] C.T.C. 2193 (T.R.B.).

Caouette v. M.N.R., [1984] C.T.C. 2447 (Tax C.C.) and Gault, Estate of v. MNR., [1978] C.T.C. 2028 (T.R.B.). In both cases, the original notice of objection was sent to the Board on the 91st day. Supra, note 7 .

o6. Elliot v. M.N.R., [1978] C.T.C. 2919 (T.R.B.).

67. Kidd v. M.N.R., [1983] C.T.C. 2747 (Tax C.C.). Also see Mirotta v. M.N.R., [1978] C.T.C. 2922 (T.R.B.). 
process for justice if the lack of exercise produced a result which the individual deemed to be unjust. ${ }^{71}$

The unconstrained vision would offer the perspective that if the individual did not utilize a right through indifference, inability, or lack of awareness, and the result was an injustice, that individual could and should look to the judicial system for a remedy. To the extent that an individual is precluded from utilizing the positive right to contest an assessment, by comparison to the individual who had given due consideration to the situation, an injustice has resulted. To correct and maximize the positions, the unconstrained vision may have accepted the requests for extension. For this vision, the substance test would have produced equality of results. ${ }^{72}$

While it would appear that the Courts have accepted unusual circumstances as necessary for successful applications for extension, it would also appear that less than peculiar fact situations have succeeded. ${ }^{73}$ The common evidence which distinguished these fact situations from other unsuccessful applications was that each of the taxpayers was facing a penalty or criminal charges as a result of the initial assessment. ${ }^{74}$ The Courts concluded that to the extent punitive action was being considered, it would be just and equitable to grant the extensions in order for the affected taxpayers to object to the proposed action.

The constrained vision would most likely reject the applications as being beyond the parameters of accepted judicial decision making. The fact that other results may occur from the assessment would not alter the process of denying the applications. It would not appear that a potential outcome of a yet to be decided court challenge would fall within the boundary of unusual circumstances. All previous decisions had been rendered on historic fact and had not considered possible future ramifications of rejecting the applications. If such had been the case, a potential increase in tax liability would have been sufficient for success in most, if not all, applications. Outcomes of this magnitude would have defeated the law as interpreted by those holding this vision.

71. Robert Nozick, the proponent of the minimalist state, states that by accepting minimal intervention, an individual should not expect a right of support from the state. See K. Lebacqz, Six Theories of Justice, (Minneapolis: Augsberg, 1986) at 51-65.

72. At this juncture, an obvious question to be answered is what effect, if any, would insufficient attention to the matter on the part of Revenue Canada have on an application for extension. In Demeria v. M.N.R., [1984] C.T.C. 2448 (Tax C.C.), the Court found that the taxpayer had not given sufficient attention to the matter to warrant acceptance of the application. The Court did find, however, that Revenue Canada had also not assisted in the process by not delivering certain documentation and correspondence to the taxpayer in a timely manner. Because of the inattention to the case by government officials, the application was successful.

73. See Viens v. M.N.R., [1978] C.T.C. 3018 (T.R.B.); Marquis, F. Ltée. v. M.N.R., [1982] C.T.C. 2651 (T.R.B.), and Deerhurst Resorts Lid. v. M.N.R., [1989] 2 C.T.C. 2082 (Tax C.C.). The Courts apparently would have rejected Mirotta, supra, note 67 , but for the possibility of penalties being imposed.

74. For a review of the penalty provisions of the Act, see E. Harris, "Civil Penalties Under the Income Tax Act", Corporate Management Tax Conference 1988, (Toronto: Canadian Tax Foundation, 1988) at 9:1 - 9:24. 


\section{CONCLUSION}

As stated previously, the conditions precedent found in subsection 167(5) of the Act constitute the narrowly interpreted parameters of the constrained vision. Notwithstanding the somewhat inconsistent application of the timing process which commences the objection procedure, it would appear that the Courts have applied the constrained vision's perspective of not second-guessing the exercise of discretion. Even where the Court possessed the capacity to administer the rules in a more permissive fashion, such as interpreting the phrase "as soon as circumstances permit", they have rejected this tolerant approach in favour of the more restrictive view espoused by those holding the constrained vision. Comparisons of the equality and substance of results and the reasonableness test have given way to the impersonal application and form of the judicial process.

In the opinion of the Court, the circumstances which warrant a finding of just and equitable have seldom deviated from the process or constrained perspective. With the exception of the prospect of impending penalties or criminal charges, the view of the Court has not strayed from the initial judgment articulated in Savory Beach, some twenty years ago, wherein circumstances which would justify a successful application were modified by the adjective "exceptional". It would also appear that the Courts have not embraced the more permissive nature of the section notwithstanding that the specific impetus of the change in construction was to remove the bonds from the Court's discretion. The Courts, by and large, have refused to open the door of the unconstrained vision, and, in so doing, have failed to recognize the object and spirit of the legislation. ${ }^{75}$ Future successful applications would appear to be obliged to meet the exceptional, rather than discretionary, criteria.

75. Object and spirit has now generally been construed as a "words in context" approach when determining legislative intent. This construction was a result of the Supreme Court's decision in Stubart Investments Ltd. v. The Queen, [1984] C.T.C. 294 (S.C.C.). For a review of the Stubart decision, see V. Morgan, "Stubart: What the Courts Did Next", (1987) Canadian Tax Journal 34 at 155 . 
the legislation. ${ }^{75}$ Future successful applications would appear to be obliged to meet the exceptional, rather than discretionary, criteria.

75. Object and spirit has now generally been construed as a "words in context" approach when determining legislative intent. This construction was a result of the Supreme Court's decision in Stubart Investments Ld. v. The Queen, [1984] C.T.C. 294 (S.C.C.). For a reivew of the Stubart decision, see V. Morgan, "Stubart: What the Courts Did Next", (1987) Canadian Tax Journal 34 at 155. 